\title{
Detection of EGFR and BRAF mutations by competitive allele-specific TaqMan polymerase chain reaction in lung adenocarcinoma
}

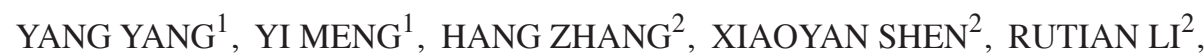 \\ LIXIA YU ${ }^{2}$, BAORUI LIU ${ }^{2}$ and LIFENG WANG ${ }^{2}$
}

\begin{abstract}
${ }^{1}$ Department of Oncology, The Affiliated Taikang Xianlin Drum Tower Hospital of Medical School of Nanjing University, Nanjing, Jiangsu 210046; ${ }^{2}$ The Comprehensive Cancer Centre of Drum Tower Hospital, Medical School of Nanjing University and Clinical Cancer Institute of Nanjing University, Nanjing, Jiangsu 210008, P.R. China
\end{abstract}

Received September 14, 2016; Accepted October 24, 2017

DOI: $10.3892 / \mathrm{ol} .2017 .7652$

\begin{abstract}
Epithelial growth factor receptor (EGFR)-tyrosine kinase inhibitors are the standard first-line treatment for patients with metastatic non-small cell lung cancer (NSCLC) expressing sensitive EGFR-mutants. Other drugs target different driver mutants, including the serine/threonine-protein kinase B-raf (BRAF) inhibitor dabrafenib, which has exhibited promising efficacy for treating patients with metastatic BRAF-mutated NSCLC. Therefore, identifying patients carrying mutations that may be treated using targeted therapies is important. However, the methods of molecular detection presently applied in clinical practice, particularly detection of BRAF in NSCLC patients, require further investigation. Therefore, more sensitive and economic methods are required. The present study applied the competitive allele-specific TaqMan polymerase chain reaction (CastPCR) technology to the molecular detection of EGFR (del2235-2249, del2236-2250, T790M, L858R) and BRAF (V600E, G469A, D594G) mutations in 144 treatment-naive patients with lung adenocarcinoma, and analyzed the association between the mutation rates and patients' clinicopathological features. 51.4\% (74/144) cases were identified harboring EGFR mutations. A total of $40.3 \%$ (58/144) patients carried sensitizing mutations (exon 19 deletion or L858R) and $14.6 \%(21 / 144)$ carried T790M mutations. 6.9\% (10/144) mutation-positive patients were double-mutated. Total EGFR mutation rate was significantly increased in female compared with that of males ( 60.9 vs. $43.8 \%, \mathrm{P}<0.05)$, in non-smokers
\end{abstract}

Correspondence to: Dr Lifeng Wang, The Comprehensive Cancer Centre of Drum Tower Hospital, Medical School of Nanjing University and Clinical Cancer Institute of Nanjing University, 321 Zhongshan Road, Nanjing, Jiangsu 210008, P.R. China

E-mail: lifengwang@nju.edu.cn

Key words: epithelial growth factor receptor, serine/threonine-protein kinase B-raf, non-small cell lung cancer, competitive allele-specific TaqMan polymerase chain reaction compared with that of smokers $(62.8$ vs. $34.5 \%, \mathrm{P}<0.05)$. In total, $8.3 \%(12 / 144)$ patients were identified with BRAF mutations. $16.7 \%$ were V600E (2/12) and $83.3 \%$ (10/12) were non-V600E mutants. Among the 10 non-V600E mutations, D594G accounted for 90.0\% (9/10) and G469A accounted for $10.0 \%(1 / 10)$. Statistical analysis demonstrated that the BRAF mutation rate was not associated with any of the following clinicopathological features: Sex, age, smoking history, clinical stages, distant metastasis, differentiation degree, tumor size and regional lymph node metastasis $(\mathrm{P} \geq 0.05)$. CastPCR technology is a robust method with high sensitivity for the molecular detection of EGFR and BRAF mutations in clinical formalin-fixed paraffin-embedded samples.

\section{Introduction}

Lung cancer is one of the most common types of cancer and the leading cause of cancer-associated mortality worldwide. According to data from the World Health Organization GLOBOCAN study (1), the estimated number of new cases was 1.8 million in 2012 (12.9\% of the total diagnosed cancer cases), and lung cancer was estimated to be responsible for nearly one in five (1.59 million deaths, $19.4 \%$ of the total) incidences of mortality from cancer. The traditional platinum-based chemotherapeutic modalities have, for the past few decades, reached a therapeutic plateau (2); fortunately, the identification of driver mutations, including those to the epithelial growth factor receptor (EGFR) and anaplastic lymphoma kinase, and the use of targeted therapy have improved progression-free survival, overall response rate and quality of life of patients (3-9).

At present, driver mutations are continuing to be identified; there are a number of clinical trials regarding targeted therapies in progress $(10,11)$. Serine/threonine-protein kinase B-raf (BRAF) is a member of the RAF kinase family, which serves an important function in the MAPK signaling pathway $(12,13)$. Once abnormally activated, the kinases transmit extracellular signals that result in the promotion of cell proliferation, survival and invasion $(14,15)$. In non-small cell lung cancer (NSCLC), BRAF inhibitors are showing promise according to the results of a phase II clinical trial (no. NCT01336634) assessing the 
clinical activity of dabrafenib in metastatic NSCLC patients (of which 96\% were adenocarcinomas) with BRAF V600E mutations (16). However, the incidence of BRAF mutations in NSCLC has not been conclusively determined. The reported incidence differs greatly and ranges between 0.5 and 9\% (17). BRAF mutations are observed almost exclusively in adenocarcinomas (18); however, other details remain to be elucidated.

To identify as many mutation-positive patients who may benefit from targeted therapies as possible, a rapid and robust molecular detection assay is required. In clinical practice in China, the detection of genetic mutations is usually performed by Sanger sequencing and the amplification refractory mutation system (ARMS) (19). Sanger sequencing is considered the 'gold standard' genotyping technique, owing to its low false-positive rate and high specificity (20). However, it has a number of disadvantages, including low sensitivity, the time taken to perform the assay, the requirement of high-quality tissue samples and the necessity of manual interpretation (21). Although the sensitivity (1\%) (22) of ARMS is increased compared with that of Sanger sequencing (10-25\%) (20,23-26), and certain other disadvantages of Sanger sequencing may be overcome by ARMS, it remains inferior to certain novel testing methods (27). Recently, gene detection using next generation sequencing (NGS) technology has attracted extensive attention; however, these methods are time-consuming and too expensive for the detection of a specific gene allele. Besides, the data produced by NGS is not easy for routine clinical analysis. Competitive Allele-Specific TaqMan ${ }^{\circledR}$ polymerase chain reaction (CastPCR) has a high sensibility and specificity; its allele-specific primer and locus-specific primer guarantee the amplification of the mutant allele, while an oligonucleotide blocker suppresses amplification of the wild type allele (28). Bao et al (29) demonstrated that CastPCR technology may robustly detect mutated alleles in a wild type background as low as $0.1 \%$ and has $>99 \%$ concordance with other technologies, including PCR-based technology and sequencing. Although small sample sizes of 30 were used, Didelot et al (30) and Roma et al (22) concluded that CastPCR is highly sensitive for the specific detection of EGFR mutations in NSCLC clinical samples. Li et al (31) demonstrated that CastPCR technology is a valuable validation tool for NGS detection of multiple gene mutations, including those to EGFR.

To the best of our knowledge, the present study is the first to evaluate the validity of CastPCR in EGFR and BRAF mutation detection in >100 formalin-fixed paraffin-embedded (FFPE) samples of lung adenocarcinoma. The current study also investigated the association between EGFR/BRAF mutation incidence and the clinicopathological features of patients.

\section{Materials and methods}

Materials. A total of 144 FFPE samples of lung adenocarcinoma patients diagnosed between November 2010 and November 2015 were collected from Nanjing Drum-Tower Hospital (Nanjing, China). The sex ratio of the 144 patients enrolled was 1.25 (male:female) and the age range was between 37 and 75 years (mean, 60.8 years). Clinicopathological features are provided in Table I. Each FFPE sample was cut into $4-\mu \mathrm{m}$-thick slices. For every FFPE sample, a random slice underwent hematoxylin and eosin staining for $60 \mathrm{~min}$ at room temperature (CoverStainer; Agilent Technologies, Inc., Santa Clara, CA, USA). A senior pathologist from the Pathology Department of Drum Tower Hospital identified the area of tumor tissue of the stained sample using a light microscope (magnification, $\mathrm{x} 40$ ), and a sample of tumor tissue (0.6-1.0 $\left.\mathrm{mm}^{2}\right)$ was removed and placed into an Eppendorf tube for later DNA extraction. The clinicopathological features, including sex, age, smoking history, distant metastasis, clinical stages of patients (according to the 7 th edition of tumor-node-metastasis staging for lung tumors outlined by the American Joint Committee on Cancer) (32), differentiation of tumor, and, for patients that underwent surgery, information of tumor size and regional lymph node metastasis were collected. Ethical approval for the present study was provided by The Medical Ethics Committee of Drum Tower Hospital. All patients provided written informed consent for the publication of the present study.

DNA extraction. DNA was extracted using the TIANamp FFPE DNA kit (Tiangen Biotech Co., Ltd., Beijing, China) according to manufacturer's instructions from the $0.6-1.0 \mathrm{~mm}^{2}$ tumor tissue on the tissue section.

CastPCR. Extracted DNA samples from FFPE tissues were analyzed by the following Taqman ${ }^{\circledR}$ Mutation Detection Assay kits(Life Technologies; ThermoFisherScientific,Inc., Waltham, MA, USA): EGFR_reference (Catalog Number: 4465807, Assay ID: Hs00000173_rf) and BRAF_reference (Catalog Number: 4465807, Assay ID: Hs00000172_rf); EGFR_6223_ mu (Catalog Number: 4465804, Assay ID: Hs00000156_mu), EGFR_6225_mu (Catalog Number: 4465804, Assay ID: Hs00000157_mu), EGFR_6224_mu (Catalog Number: 4465804, Assay ID: Hs00000102_mu) and EGFR_6240_mu (Catalog Number: 4465804, Assay ID: Hs00000106_mu) for detecting the 2235-2249 del, 2236-2250 del,L858R and T790M, respectively; BRAF_460_mu (Catalog Number: 4465804, Assay ID: Hs00001351_mu), BRAF_467_ mu (Catalog Number: 4465804, Assay ID: Hs00000996_mu) and BRAF_475_mu (Catalog Number: 4465804, Assay ID: Hs00001384_mu) for detecting G469A, D594G and V600E, respectively. The PCR reaction was performed using a Stratagene MX3000P real-time PCR system (Stratagene; Agilent Technologies, Inc.). The PCR conditions were as follows: $95^{\circ} \mathrm{C}$ for $10 \mathrm{~min}$, followed by 5 cycles at $92^{\circ} \mathrm{C}$ for $15 \mathrm{sec}$ and $58^{\circ} \mathrm{C}$ for $1 \mathrm{~min}$, then 40 cycles at $92^{\circ} \mathrm{C}$ for $15 \mathrm{sec}$ and $60^{\circ} \mathrm{C}$ for $1 \mathrm{~min}$.

Prior to the detection of clinical specimens, the limit of detection (LOD) of CastPCR for detecting EGFR and BRAF mutations was assessed and a dilution of mutant alleles in a wild-type background was prepared using DNA extracted from the corresponding cell lines. The wild-type background was set as DNA extracted from EGFR and BRAF mutation-negative cell line A549. Cell line PC9 was mutation-positive for deletion (2235-2249) in exon 19 of EGFR, cell line H1975 was mutation-positive for T790M in exon 20 and L858R in exon 21 of EGFR and cell line A375 was positive for the V600E mutation in exon 15 of BRAF. All cell lines were obtained from our own laboratory, and were cultured in RPMI-1640 (Gibco; Thermo Fisher Scientific, Inc.) supplemented with $10 \%$ fetal 
Table I. Clinicopathological features of the 144 patients with adenocarcinoma.

\begin{tabular}{|c|c|}
\hline Clinicopathological feature & Patients, n (\%) \\
\hline \multicolumn{2}{|l|}{ Sex } \\
\hline Male & $80(55.6)$ \\
\hline Female & $64(44.4)$ \\
\hline \multicolumn{2}{|l|}{ Age, years } \\
\hline$\geq 60$ & $81(56.3)$ \\
\hline$<60$ & $63(43.7)$ \\
\hline \multicolumn{2}{|l|}{ Smoking history } \\
\hline Smokers $^{\mathrm{a}}$ & $58(40.3)$ \\
\hline Non-smokers & $86(59.7)$ \\
\hline \multicolumn{2}{|l|}{ Clinical stages $^{b}$} \\
\hline I-III & $78(54.2)$ \\
\hline IV & $66(45.8)$ \\
\hline \multicolumn{2}{|l|}{ Distant metastasis } \\
\hline Yes & $63(43.7)$ \\
\hline No & $81(56.3)$ \\
\hline \multicolumn{2}{|l|}{ Differentiation degree } \\
\hline Well & $17(11.8)$ \\
\hline Medium/poor & $127(88.2)$ \\
\hline \multicolumn{2}{|l|}{ Tumor size, $\mathrm{cm}^{\mathrm{c}}$} \\
\hline$\leq 3$ & $36(46.8)$ \\
\hline$>3$ & $41(53.2)$ \\
\hline \multicolumn{2}{|l|}{ Lymph node metastasis ${ }^{c}$} \\
\hline Yes & $34(44.2)$ \\
\hline No & $43(55.8)$ \\
\hline
\end{tabular}

bovine serum (Minhai Bio Engineering, Lanzhou, China). The cells were incubated at $37^{\circ} \mathrm{C}$ in a humidified atmosphere of $5 \%$ $\mathrm{CO}_{2}$. In addition, the cell lines were used within ten passages after thawing of frozen cells. All the mutations of the cell lines were confirmed using pyrosequencing by Shanghai HuaGene Biotech Company (Shanghai, China). DNA extracted from cell lines (as aforementioned) was initially diluted at $20 \mathrm{ng} / \mu \mathrm{l}$ and then serial dilutions of 1:100, 1:500, 1:1,000 and 1:2,000 were performed. The prepared DNA was put into the CastPCR reaction wells. CastPCR was run on a 96-well plate, and each well had a final volume of $10 \mu$ l. This included $5 \mu 1$ Taqman ${ }^{\circledR}$ Genotyping Master Mix (2X) (Life Technologies; Thermo Fisher Scientific, Inc.), $2 \mu \mathrm{l}$ prepared gDNA sample, $2 \mu \mathrm{l}$ nuclease-free water (Beyotime Institute of Biotechnology, Haimen, China) and $1 \mu \mathrm{l} \mathrm{TaqMan}{ }^{\circledR}$ Mutation Detection Assay (10X) (Life Technologies; Thermo Fisher Scientific, Inc.) according to the manufacturer's protocol. The detection of each DNA sample was repeated three times. The concentration of extracted DNA was determined by a NanoDrop spectrophotometer (NanoDrop Technologies, Inc., Thermo Fisher
Table II. Associations between EGFR incidence and clinicopathological features.

\begin{tabular}{|c|c|c|}
\hline Clinicopathological feature & Mutated cases, $\mathrm{n}(\%)$ & P-value \\
\hline Sex & & 0.040 \\
\hline Male & $35(43.8)$ & \\
\hline Female & $39(60.9)$ & \\
\hline Age, years & & 0.120 \\
\hline$\geq 60$ & $37(45.7)$ & \\
\hline$<60$ & $37(58.7)$ & \\
\hline Smoking history & & 0.001 \\
\hline Smokers $^{\mathrm{a}}$ & $20(34.5)$ & \\
\hline Non-smokers & $54(62.8)$ & \\
\hline Clinical stages ${ }^{\mathrm{b}}$ & & 0.302 \\
\hline I-III & $37(47.4)$ & \\
\hline IV & $37(56.1)$ & \\
\hline Distant metastasis & & 0.378 \\
\hline Yes & $35(55.6)$ & \\
\hline No & $39(48.1)$ & \\
\hline Differentiation degree & & 0.370 \\
\hline Well & $7(41.2)$ & \\
\hline Medium/poor & $67(52.8)$ & \\
\hline Tumor size, $\mathrm{cm}$ & & 0.553 \\
\hline$\leq 3$ & $16(44.4)$ & \\
\hline$>3$ & $21(51.2)$ & \\
\hline Lymph node metastasis & & 0.962 \\
\hline Yes & $16(47.1)$ & \\
\hline No & $20(46.5)$ & \\
\hline
\end{tabular}

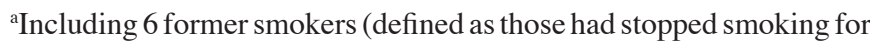
$\geq 1$ year) (66). ${ }^{\mathrm{b}}$ According to the 7 th edition of tumor-node-metastasis staging for lung tumors signed by the American Joint Committee on Cancer (32). EGFR, epidermal growth factor receptor.

Scientific, Inc.), and adjusted to a concentration of $10 \mathrm{ng} / \mu \mathrm{l}$ for further analysis. For G469A and D594G, no available mutation positive cell lines could be obtained; therefore, the assessment was not performed. However, according to the manufacturer, the sensitivity of detecting the two mutations was $0.1 \%$.

DNA is qualified for detection when the $\mathrm{Cq}$ value (gene reference assay) is between 17-33, or re-extraction would be performed for the sample. The mutation status was determined by calculating the $\Delta \mathrm{Cq}$ value between amplification reactions for a mutant allele assay and a corresponding gene rleference assay, namely $\Delta \mathrm{Cq}=\mathrm{Cq}$ (mutant allele assay) $-\mathrm{Cq}$ (gene reference assay) as outlined by the TaqMan ${ }^{\circledR}$ Mutation Detection Assay handbook provided by CastPCR (33). The cut-off $\Delta \mathrm{Cq}$ values provided by Life Technologies were used. The mutation was detected if the $\Delta \mathrm{Cq} \leq \Delta \mathrm{Cq}$ cut-off and mutation was not detected if the $\Delta \mathrm{Cq}>\Delta \mathrm{Cq}$ cut-off. According to the cut-off $\Delta \mathrm{Cq}$ values provided by Life Technologies, the cut-off $\Delta$ Cq values of EGFR 2235-2249 del, 2236-2250 del, L858R and BRAF V600E, G469A, D594G are 9.96; That of EGFR T790M is 9.61 . 
Table III. Patients with BRAF mutations $(n=12)$.

\begin{tabular}{lccccc}
\hline Patient number & Sex & Distant metastasis & Smoking history & BRAF mutation & EGFR mutation \\
\hline T14 & M & Yes & Yes & V600E & No \\
S29 & F & No & No & V600E & No \\
S04 & M & No & Yes & D594G & 19Del \\
S37 & M & No & Yes & D594G & No \\
T06 & M & Yes & No & D594G & T790M \\
S55 & M & No & No & D594G & L858R \\
T21 & M & Yes & No & D594G & 19Del \\
T16 & M & Yes & No & D594G & 19Del \\
S03 & F & No & No & D594G & No \\
S46 & F & No & No & D594G & 19Del \\
S48 & F & No & No & G469A & L858R \\
S07 & M & No & No & No \\
\hline
\end{tabular}

BRAF, serine/threonine-protein kinase B-raf; EGFR, epithelial growth factor receptor; 19Del, exon 19 deletion; M, male; F, female; S, patient received surgery; $\mathrm{T}$, patient did not receive surgery.

Statistical analysis. Data were presented as mean \pm standard deviation. Statistical analyses were performed using SPSS software (version 18; SPSS, Inc., Chicago, IL, USA). Variables measured in the study were assessed for association using the $\chi^{2}$ test or Fisher's exact test, as appropriate. $\mathrm{P}<0.05$ was considered to indicate a statistically significant difference. All P-values were two-sided.

\section{Results}

LOD for EGFR and BRAF. The $\triangle \mathrm{Cq}$ value was $8.56 \pm 0.57$, $9.01 \pm 0.66$ and $9.16 \pm 0.26$ for $1: 1,000$ exon 19 del, 1:1,000 L858R and 1:100 T790M detection, respectively. The $\Delta \mathrm{Cq}$ value was $9.90 \pm 0.04$ for 1:1,000 V600E detection. Therefore, in accordance with the sensitivity value provided by the manufacturer, the LOD for EGFR exon 19 deletion and L858R were $0.1 \%$, that of $\mathrm{T} 790 \mathrm{M}$ was $1 \%$ and that of BRAF V600E was $0.1 \%$.

EGFR mutations. In total, 51.4\% (74/144) patient samples were identified as harboring EGFR mutations: $40.3 \%$ (58/144) patients carried EGFR sensitizing mutations (exon 19 deletion or/and L858R) and 14.6\% (21/144) carried EGFR T790M mutations. In addition, 6.9\% (10/144) mutation-positive patients were EGFR double-mutated: 3 patients had exon 19 deletions and T790M, 5 had exon 19 deletion and L858R, and 2 had T790M and L858R.

Statistical analysis demonstrated that the EGFR mutation rate was significantly increased in female patients compared with that in males (60.9 vs. $43.8 \%, \mathrm{P}<0.05)$, in non-smokers compared with that in smokers $(62.8$ vs. $34.5 \%, \mathrm{P}<0.05)$, as expected (Table II). Age, clinical stage (stratified as stage I-III and stage IV), distant metastasis, degree of differentiation, tumor size and metastasis of regional lymph nodes (the last two features applying to surgical patients only) were not associated with EGFR mutation status $(\mathrm{P} \geq 0.05$; Table II).
BRAF mutations. In total, $8.3 \%(12 / 144)$ of patients were identified as possessing BRAF mutations: $16.7 \%$ (2/12) were V600E mutations and $83.3 \%$ (10/12) were non-V600E mutations. Among the 10 non-V600E mutations, D594G accounted for $90.0 \%$ (9/10) of mutations and G469A accounted for $10.0 \%$ (1/10) (Table III).

Statistical analysis demonstrated that the BRAF mutation rate was not associated with any of the clinicopathological features assessed in the present study, including sex, age, smoking history (including the stratified classification of smokers, former smokers and non-smokers; data not shown), distant metastasis, degree of differentiation, tumor size and metastasis of regional lymph nodes (the last two features applying to surgical patients only; $\mathrm{P} \geq 0.05$; Table IV).

\section{Discussion}

Identifying EGFR as an oncogene and the successful application of EGFR-tyrosine kinase inhibitors (TKIs) have revolutionized the treatment of NSCLC. Personalized medicine that targets driver mutations using precision medicine is key to eliciting an improved therapeutic effect. Molecular detection of driver mutations within the tumor tissue of patients may enable precision treatment of lung cancer.

CastPCR technology is highly specific and sensitive and may detect small quantities of mutated DNA in a sample that contains large amounts of normal, wild-type genomic DNA. Tan et al $(34,35)$ demonstrated that CastPCR exhibits TaqMan ${ }^{\circledR}$ assay-like sensitivity, linearity and dynamic range and may detect a single mutant molecule in the presence of 1 million wild-type molecules. CastPCR may be performed to detect certain mutant alleles and is cost-effective (30,34-37). Compared with ARMS, the most commonly used method in clinical practice in China, CastPCR has improved sensitivity and specificity owing to its oligonucleotide blocker that suppresses the wild-type allele, which does not exist in ARMS (28). Previous studies have demonstrated this in 
Table IV. Association between BRAF incidence and clinicopathological features.

\begin{tabular}{|c|c|c|}
\hline $\begin{array}{l}\text { Clinicopathological } \\
\text { feature }\end{array}$ & $\begin{array}{l}\text { BRAF-mutated } \\
\text { cases, n }(\%)\end{array}$ & P-value \\
\hline Sex & & 0.418 \\
\hline Male & $8(10.0)$ & \\
\hline Female & $4(6.3)$ & \\
\hline Age, years & & 0.879 \\
\hline$\geq 60$ & $7(8.6)$ & \\
\hline$<60$ & $5(7.9)$ & \\
\hline Smoking history & & 0.838 \\
\hline Smokers $^{\mathrm{a}}$ & $4(6.9)$ & \\
\hline Non-smokers & $8(9.3)$ & \\
\hline Clinical Stages ${ }^{\mathrm{b}}$ & & 0.364 \\
\hline I-III & $8(10.3)$ & \\
\hline IV & $4(6.1)$ & \\
\hline Distant metastasis & & 0.171 \\
\hline Yes & $3(4.8)$ & \\
\hline No & $9(11.1)$ & \\
\hline Differentiation degree & & 1.000 \\
\hline Well & $1(5.9)$ & \\
\hline Medium/poor & $11(8.7)$ & \\
\hline Tumor size, $\mathrm{cm}^{\mathrm{c}}$ & & 1.000 \\
\hline$\leq 3$ & $4(11.1)$ & \\
\hline$>3$ & $4(9.8)$ & \\
\hline Lymph node metastasis $^{c}$ & & 0.981 \\
\hline Yes & $3(8.8)$ & \\
\hline No & $5(11.6)$ & \\
\hline
\end{tabular}

ancluding 6 former smokers (defined as those that had stopped smoking for $\geq 1$ year) (66). ${ }^{b}$ According to the 7 th edition of Tumor-Node-Metastasis staging for lung tumors designed by the American Joint Committee on Cancer (32). ' In total, 77 patients underwent surgical resection. BRAF, serine/threonine-protein kinase B-raf.

multiple types of malignant tumor $(22,38,39)$. Two previous studies used CastPCR technology to validate detected mutation results obtained by NGS $(31,40)$. For economic consideration in clinical practice, the present study evaluated the molecular detection of EGFR and BRAF mutations using CastPCR in 144 lung adenocarcinoma samples.

Although previous studies have performed EGFR mutation detection in NSCLC using CastPCR, the number of patients was relatively small, with no more than 30 samples included $(22,30,41)$. Therefore, the present study collected samples from 144 patients with lung adenocarcinoma in order to verify its sensitivity and feasibility in larger clinical samples.

The frequency of EGFR mutations in lung adenocarcinoma was $51.4 \%(74 / 144)$ in the present study, which was concordant with that in previous studies conducted in Asia $(3,42,43)$. In the present study, $40.3 \%$ (58/144) of patients exhibited EGFR mutations, values close to those obtained by Shi et al and Wu et al $(43,44)$. In the present study, EGFR mutations appeared more frequently in women than in men
(60.9 vs. $43.8 \%, \mathrm{P}=0.04)$, more frequently in non-smokers than in smokers (62.8 vs. $34.5 \%, \mathrm{P}=0.001)$, as expected $(43,45-47)$.

To identify the LOD of CastPCR for detecting EGFR mutations, EGFR-mutation-positive and -negative cells were mixed. The LOD for exon 19 deletion and L858R was $0.1 \%$ and that of $\mathrm{T} 790 \mathrm{M}$ was $1 \%$, which matched the LOD provided by the manufacturer. Considering the LOD of CastPCR, EGFR mutation detection in T790M (1\%) may not be satisfying compared with that of exon 19 deletion and L858R (0.1\%). In EGFR-mutated NSCLC, the reported incidence of de novo T790M substitution varied, ranging between 0 and $78.9 \%$ worldwide (48). This range of figures was primarily associated with different detection methods (Table V). The LOD of different methods for detecting T790M mutations is provided (Table VI).

In the present study, 6.9\% (10/144) of patients were found to possess double mutations. EGFR double mutations have been reported in previous studies (49-55). For example, Zhang et al (54) found that 6.5\% (5/77) of lung adenocarcinoma patients possessed double mutations. Masago et al (51) found that this figure was 4.4\% (4/90). In EGFR-mutated lung adenocarcinoma, the double mutation rate was $13.5 \%(10 / 74)$ in the present study. Keam et al (50) found a double mutation incidence $1.5 \%$ (4/274) in Japanese EGFR-mutated lung adenocarcinoma patients. The incidence of double mutation in the present study may have been increased due to the increased sensitivity of the CastPCR technology. Among double EGFR-mutated patients in the present study, 3 were exon 19 deletions and T790M, 5 were exon 19 deletions and L858R and 2 were T790M and L858R. Exon 19 deletions and L858R are considered sensitizing mutations since the majority of patients harboring this type of mutation respond to EGFR-TKIs (55). The clinical significance of exon 19 deletions/L858R and T790M is, to the best of our knowledge, unknown.

Blakely et al (56) found that EGFR-TKI treatment may lead to the expansion of BRAF V600E-expressing tumor cells, resulting in acquired EGFR-TKI resistance that may be reversed by treatment with a BRAF inhibitor, which implies that the BRAF V600E mutation could be one of the mechanisms of EGFR-TKI resistance. Recently, a phase II clinical trial (no. NCT01336634) has made its results public (16). Dabrafenib exhibited clinical activity in BRAF V600E-positive metastatic NSCLC; these results indicated that dabrafenib could represent a treatment option for a population of patients with limited therapeutic options (16). Certain studies (57-62) have evaluated BRAF mutations in NSCLC samples; however, the use of CastPCR in assessing these mutations has not, to the best of our knowledge, been reported. Therefore, the present study performed BRAF mutation detection using CastPCR in 144 lung adenocarcinoma samples.

The BRAF gene is mutated in 1-5\% of NSCLC cases, and the majority of these are mutated in adenocarcinomas $(17,18,61,62)$. When NGS was used, the incidence of BRAF mutation appeared to be $6.5 \%$ (33/510) (63). In the present study, this incidence was $8.3 \%$, closer to the result obtained by NGS $(17,63)$. The incidence of BRAF mutation in the present study may have been increased since BRAF mutations are more common in Asian populations $(59,60)$. Compared with that of Sanger sequencing (64), CastPCR exhibited superior sensitivity in detecting BRAF mutations in clinical FFPE samples in our 
Table V. Baseline T790M mutation rates of non-small cell lung cancer.

\begin{tabular}{|c|c|c|c|c|}
\hline Author, year & Methods & Baseline T790M mutation $^{\mathrm{a}}(\%)$ & Analytical sensitivity & (Refs.) \\
\hline Maheswaran et al, 2008 & $\begin{array}{l}\text { Direct sequencing } \\
\text { Scorpion ARMS }\end{array}$ & $\begin{array}{c}0 / 26(0) \\
10 / 26(38)\end{array}$ & $\begin{array}{c}\text { NR } \\
0.20 \%\end{array}$ & $(48)$ \\
\hline Sequist et al, 2008 & Direct sequencing & $2 / 34(5.9)$ & NR & $(72)$ \\
\hline Nakamura et al, 2011 & MBQ-QP & $3 / 32(9.4)$ & $0.40 \%$ & $(73)$ \\
\hline Rosell et al, 2011 & TaqMan assay + PNA & $45 / 129(34.9)$ & $0.02 \%$ & (74) \\
\hline Wu et al, 2011 & Direct sequencing & $6 / 627(1)$ & NR & $(75)$ \\
\hline Fujita et al, 2012 & Colony hybridization & $30 / 38(78.9)$ & $0.01 \%$ & $(76)$ \\
\hline Su et al, 2012 & $\begin{array}{l}\text { Direct sequencing } \\
\text { MALDI-TOF MS }\end{array}$ & $\begin{array}{c}2 / 76(2.6) \\
23 / 76(30.26)\end{array}$ & $\begin{array}{c}\text { NR } \\
2.20 \%\end{array}$ & $(77)$ \\
\hline Sakai et al, 2013 & SABER & $2 / 28(2)$ & $0.30 \%$ & $(78)$ \\
\hline Costa et al, 2014 & TaqMan probe + PNA & $62 / 95(65.3)$ & $0.02 \%$ & (79) \\
\hline Yu et al, 2014 & MALDI-TOF MS & $11 / 579(2)$ & NR & $(80)$ \\
\hline
\end{tabular}

${ }^{a}$ Among patients with epithelial growth factor receptor mutations. ARMS, amplification refractory mutation system; NR, not reported; MBQ-QP, mutation-biased polymerase chain reaction-quenching probe; PNA, peptide-nucleic acid; SABER, single-allele base-extension reaction; MALDI-TOF-MS, matrix-assisted laser desorption/ionization time of flight mass spectrometry.

Table VI. LOD of different methods detecting T790M mutations.

\begin{tabular}{|c|c|c|c|}
\hline Author, year & Method & LOD, $\%$ & (Refs.) \\
\hline Sequist et al, 2008 & Direct sequencing & $25-35$ & $(72)$ \\
\hline Miyazawa et al, 2008 & PNA-LNA PCR & 0.1 & $(81)$ \\
\hline Li et al, 2009 & COLD-PCR & 0.8 & $(82)$ \\
\hline Chen et al, 2009 & Scorpion ARMS & 1 & $(83)$ \\
\hline Oh et al, 2010 & Molecular beacon-PCR & 2 & $(84)$ \\
\hline Oh et al, 2011 & PNA-clamping PCR & 0.01 & $(85)$ \\
\hline Taniguchi et al, 2011 & BEAMing & 0.01 & $(86)$ \\
\hline Arcila et al, 2011 & $\begin{array}{l}\text { PCR-sequencing/FA } \\
\text { LNA-PCR-sequencing }\end{array}$ & $\begin{array}{c}12.5 \\
0.1\end{array}$ & $(87)$ \\
\hline Su et al, 2012 & $\begin{array}{l}\text { Direct sequencing } \\
\text { MALDI-TOF-MS }\end{array}$ & $\begin{array}{c}25-35 \\
1.5\end{array}$ & $(77)$ \\
\hline Guha et al, 2013 & DISSECT-PNA-LNA PCR & 0.01 & $(88)$ \\
\hline He et al, 2013 & $\begin{array}{l}\text { Direct sequencing } \\
\text { Mutant-enriched PCR }\end{array}$ & $\begin{array}{l}\text { NA } \\
0.1\end{array}$ & $(89)$ \\
\hline Rosell et al, 2011 & PNA-Taqman PCR & NA & $(74)$ \\
\hline Fujita et al, 2012 & PCR-colony hybridization & NA & $(76)$ \\
\hline Kim et al, 2013 & Pyrosequencing & NA & $(90)$ \\
\hline
\end{tabular}

LOD, limit of detection; PNA, peptide nucleic acid; LNA, locked nucleic acid; COLD-PCR, co-amplification at lower denaturation temperature-polymerase chain reaction; BEAMing, beads, emulsion, amplification, and magnetics; FA, fragment analysis; MALDI-TOF-MS, matrix-assisted laser desorption/ionization time of flight mass spectrometry; DISSECT, differential strand separation at critical temperature.

study, which is comparable with that of NGS. Previous studies demonstrated that V600E mutation accounted for at least $50 \%$ of BRAF mutations in NSCLC $(58,59,65)$. In recent years, a number of studies applying the NGS demonstrated that
non-V600E mutations represent the majority of BRAF mutations: Kinno et al (61), Zheng et al (63) and Carter et al (17) revealed that the proportion of non-V600E in BRAF-mutated NSCLC was 70.0, 78.8 and $86.0 \%$, respectively. The present 
study revealed an incidence of non-V600E BRAF mutations of $83.3 \%(10 / 12)$, similar to that demonstrated by NGS studies $(17,61,63)$. Of the 10 non-V600E-mutated patients in the present study, 75.0\% (9/12) carried D594G and 8.3\% (1/12) carried G469A, so the mutation rates were may be represented as D594G $>$ V600E $>$ G469A, which is concordant with the results obtained by Carter et al (17). Therefore, the results of the present study indicated that CastPCR is a valuable tool for the detection of BRAF mutations in clinical FFPE samples.

The present study selected certain clinicopathological features, including sex, age, smoking history, clinical stages, distant metastasis, differentiation degree, tumor size and lymph node metastasis, to identify the association between BRAF mutations and these features (Table IV). None of these clinicopathological features was associated with BRAF mutations. The association between BRAF mutation status and sex, age and smoking history was consistent with previous research $(18,66)$. In addition, the incidence among former, current and never smokers was assessed and no statistical significance was found (data not shown). At present, few studies focus on the pathological features of BRAF-mutated patients. According to Marchetti et al (65), no association was found between BRAF mutation rate and tumor size or lymph node metastasis. No association was identified between BRAF mutation and differentiation degree. EGFR mutations tend to appear in individuals that are Asian, female, non-smokers and exhibit adenocarcinoma, therefore this may aid physicians in recognizing patients who may benefit from EGFR-TKIs. Therefore it is recommended that patients should be tested for EGFR mutations in order to personalize the treatment regime. Since BRAF inhibitors have already demonstrated promise in patients with advanced stage non-small-cell lung cancer and who are BRAF-positive (16), it is necessary to obtain the information concerning the type of population that typically exhibits BRAF mutations. However, no consensus exists for this and further studies are required.

BRAF-mutated patients are provided (Table III). No significant difference was found between V600E and non-V600E mutation rates according to sex, smoking history and distant metastasis ( $\mathrm{P}>0.05$; data not shown).

A total of 7/12 patients exhibited concurrent EGFR mutations. Prior studies revealed that BRAF and EGFR mutations are exclusive in NSCLC (66-68) This phenomenon seems plausible since BRAF mutation was demonstrated as one of the mechanisms of resistance to EGFR-TKIs (69). However, concurrent BRAF and EGFR mutations were observed in further studies $(61,70)$. Among the 7 BRAF+EGFR mutation-positive patients in the present study, all of their BRAF mutations were D594G; the BRAF mutations in the BRAF+EGFR mutation-positive patients in other studies were also non-V600E $(61,70)$. Of the aforementioned BRAF mutations, V600E is the only kinase-activating one and could result in the activation of downstream mitogen-activated protein kinase kinase-extracellular signal-regulated kinase signaling pathway resistance to EGFR-TKIs (71). However, to the best of our knowledge, no evidence has demonstrated that non-V600E mutations of BRAF are resistant to EGFR-TKIs. Therefore, just as the EGFR mutations are divided into 'sensitizing' and 'resistant' categories to more accurately select treatment regimens for patients, BRAF-mutated patients should also be distinguished for $\mathrm{V} 600 \mathrm{E}$ and non-V600E status to aid the design of more pertinent experiments and clinical trials.

CastPCR is a robust method with high sensitivity for molecular detection of EGFR and BRAF mutations in FFPE samples. Therefore, EGFR and BRAF mutation detection could represent a feasible strategy in clinical practice.

\section{References}

1. Torre LA, Bray F, Siegel RL, Ferlay J, Lortet Tieulent J and Jemal A: Global cancer statistics, 2012. CA Cancer J Clin 65: 87-108, 2015.

2. Kim YH and Mishima M: Consolidation chemotherapy after concurrent chemoradiotherapy in patients with stage III non-small-cell lung cancer. J Clin Oncol 34: 767, 2016.

3. Mok TS, Wu YL, Thongprasert S, Yang CH, Chu DT, Saijo N, Sunpaweravong P, Han B, Margono B, Ichinose Y, et al: Gefitinib or carboplatin-paclitaxel in pulmonary adenocarcinoma. N Engl J Med 361: 947-957, 2009.

4. Kwong A, Shin VY, Au CH, Law FB, Ho DN, Ip BK, Wong AT, Lau SS, To RM, Choy G, et al: Evaluation on the mutation screening by next-generation sequencing in hereditary breast and ovarian cancer: Implementation of recurrent mutation panel. Cancer Res 76 (4 Suppl): P2-09-20, 2016.

5. Maemondo M, Inoue A, Kobayashi K, Sugawara S, Oizumi S, Isobe H, Gemma A, Harada M, Yoshizawa H, Kinoshita I, et al: Gefitinib or chemotherapy for non-small-cell lung cancer with mutated EGFR. N Engl J Med 362: 2380-2388, 2010.

6. Rosell R, Carcereny E, Gervais R, Vergnenegre A, Massuti B, Felip E, Palmero R, Garcia-Gomez R, Pallares C, Sanchez JM, et al: Erlotinib versus standard chemotherapy as first-line treatment for European patients with advanced EGFR mutation-positive non-small-cell lung cancer (EURTAC): A multicentre, open-label, randomised phase 3 trial. Lancet Oncol 13: 239-246, 2012.

7. Chung C: Tyrosine kinase inhibitors for epidermal growth factor receptor gene mutation-positive non-small cell lung cancers: An update for recent advances in therapeutics. J Oncol Pharm Pract 22: 461-476, 2016.

8. Solomon BJ, Mok T, Kim DW, Wu YL, Nakagawa K, Mekhail T, Felip E, Cappuzzo F, Paolini J, Usari T, et al: First-line crizotinib versus chemotherapy in ALK-positive lung cancer. N Engl J Med 371: 2167-2177, 2014.

9. Shaw AT, Kim DW, Nakagawa K, Seto T, Crinó L, Ahn MJ, De Pas T, Besse B, Solomon BJ, Blackhall F, et al: Crizotinib versus chemotherapy in advanced ALK-positive lung cancer. N Engl J Med 368: 2385-2394, 2013.

10. Shea M, Costa DB and Rangachari D: Management of advanced non-small cell lung cancers with known mutations or rearrangements: Latest evidence and treatment approaches. Ther Adv Respir Dis 10: 113-129, 2016.

11. Gorgisen G, Pehlivanoglu S, Ozes D and Ozes ON: Personalized treatment options in non-small cell lung cancer. J Managed Care Med 1, 2014.

12. Pollock PM and Meltzer PS: A genome-based strategy uncovers frequent BRAF, mutations in melanoma. Cancer Cell 2: 5-7, 2002.

13. Stephens RM, Sithanandam G, Copeland TD, Kaplan DR, Rapp UR and Morrison DK: 95-kilodalton B-Raf serine/threonine kinase: Identification of the protein and its major autophosphorylation site. Mol Cell Biol 12: 3733-3742, 1992.

14. Santarpia L, Lippman SM and El-Naggar AK: Targeting the MAPK-RAS-RAF signaling pathway in cancer therapy. Expert Opin Ther Targets 16: 103-119, 2012.

15. Carlino MS, Long GV, Kefford RF and Rizos H: Targeting oncogenic BRAF and aberrant MAPK activation in the treatment of cutaneous melanoma. Crit Rev Oncol Hematol 96: 385-398, 2015.

16. Planchard D, Kim TM, Mazieres J, Quoix E, Riely G, Barlesi F, Souquet PJ, Smit EF, Groen HJ, Kelly RJ, et al: Dabrafenib in patients with BRAF(V600E)-positive advanced non-small-cell lung cancer: A single-arm, multicentre, open-label, phase 2 trial. Lancet Oncol 17: 642-650, 2016.

17. Carter J, Tseng LH, Zheng G, Dudley J, Illei P, Gocke CD, Eshleman JR and Lin MT: Non-p.V600E BRAF mutations are common using a more sensitive and broad detection tool. Am J Clin Pathol 144: 620-628, 2015. 
18. Chen D, Zhang LQ, Huang JF, Liu K, Chuai ZR, Yang Z, Wang YX, Shi DC, Liu Q, Huang Q and Fu WL: BRAF mutations in patients with non-small cell lung cancer: A systematic review and meta-analysis. PLoS One 9: e101354, 2014.

19. He PJ, Xia HL, Fu M, et al: Detection of EGFR, KRAS, BRAF EML4-ALK fusion genes by ARMS and NGS in patients with non-small cell lung cancer. Acta Univ Med Anhui 52: 1553-1558, 2017 (In Chinese)

20. Gao J, Wu H, Wang L, Zhang H, Duan H, Lu J and Liang Z: Validation of targeted next-generation sequencing for RAS mutation detection in FFPE colorectal cancer tissues: Comparison with Sanger sequencing and ARMS-Scorpion real-time PCR. BMJ Open 6: e009532, 2016.

21. Lindeman NI, Cagle PT, Beasley MB, Chitale DA, Dacic S, Giaccone G, enkins, RB, Kwiatkowski DJ, Saldivar JS, Squire J, et al: Molecular testing guideline for selection of lung cancer patients for EGFR and ALK tyrosine kinase inhibitors: Guideline from the College of American Pathologists, International Association for the study of lung cancer, and association for molecular pathology. Arch Pathol Lab Med 137, 2013.

22. Roma C, Esposito C, Rachiglio AM, Pasquale R, Iannaccone A, Chicchinelli N, Franco R, Mancini R, Pisconti S, De Luca A, et al: Detection of EGFR mutations by TaqMan mutation detection assays powered by competitive allele-specific TaqMan PCR technology. Biomed Res Int 2013: 385087, 2013

23. Syed YY: Therascreen ${ }^{\circledR}$ EGFR RGQ PCR Kit: A companion diagnostic for afatinib and gefitinib in non-small cell lung cancer. Mol Diagn Ther 20: 191-198, 2016.

24. Rosamaria P, De Summa S, Strippoli S, Pilato B, Azzariti A, Guida G, Guida $\mathrm{M}$ and Tommasi S: The next generation of metastatic melanoma: Uncovering the genetic variants for anti-BRAF therapy response. Oncotarget 7: 25135-25149, 2016.

25. Baudhuin LM, Donato LJ and Uphoff TS: How novel molecular diagnostic technologies and biomarkers are revolutionizing genetic testing and patient care. Expert Rev Mol Diagn 12: 25-37, 2012.

26. Sharma D, Lather M, Dykes CL, Dang AS, Adak T and Singh OP: Disagreement in genotyping results of drug resistance alleles of the Plasmodium falciparum dihydrofolate reductase (Pfdhfr) gene by allele-specific PCR (ASPCR) assays and Sanger sequencing. Parasitol Res 115: 323-328, 2016.

27. Shao D, Lin Y, Liu J, Wan L, Liu Z, Cheng S, Fei L, Deng R, Wang J, Chen X, et al: A targeted next-generation sequencing method for identifying clinically relevant mutation profiles in lung adenocarcinoma. Sci Rep 6: 22338, 2016.

28. Bronte G, Silvestris N, Castiglia M, Galvano A, Passiglia F, Sortino G, Cicero G, Rolfo C, Peeters M, Bazan V, et al: New findings on primary and acquired resistance to anti-EGFR therapy in metastatic colorectal cancer: Do all roads lead to RAS? Oncotarget 6: 24780-24796, 2015.

29. Bao Y, Ching B, Mouanoutoua M, Yu W, Keys D, Desai S and Stevens J: Cancer biomarker research using castPCR technology. Cancer Res 72 (8 Suppl): S2100, 2012.

30. Didelot A, Le CD, Luscan A, Cazes A, Pallier K, Emile JF, Laurent-Puig P and Blons H: Competitive allele specific TaqMan PCR for KRAS, BRAF and EGFR mutation detection in clinical formalin fixed paraffin embedded samples. Exp Mol Pathol 92: 275-280, 2012

31. Li K, Woo C, Mouanoutoua M, Moy B, Langit E, Brzoska P, You X, Desai S, Keys D, Stevens J, et al: Validation of the Ion AmpliSeq ${ }^{\mathrm{TM}}$ comprehensive cancer panel (CCP) using castPCR ${ }^{\mathrm{TM}}$ technologies. Cancer Res 73 (8 Suppl): S4218, 2013.

32. Sobin LH, Gospodarowicz MK and Wittekind C: TNM Classification of Malignant Tumors 7th edition. Wiley-Blackwell, Oxford, 2009.

33. TaqMan ${ }^{\circledR}$ Mutation Detection Assay Competitive AlleleSpecific TaqMan ${ }^{\circledR}$ PCR. Publication Part Number 4467011 Rev. B. https://tools.thermofisher.com/content/sfs/manuals/ cms_095873.pdf. Revision date, April 2012.

34. Tan R and Brzoska P: Direct detection of rare circulating tumor cells in blood by CastPCR. J Biomol Tech 21 (3 Suppl): S30, 2010.

35. Tan R, Brzoska $P$ and Chen C: Detection of rare mutations in patient samples by comparative allele-specific TaqMan ${ }^{\circledR}$ assay-based PCR (CastPCR). Cancer Res 70 (8 Suppl): S2117, 2010.

36. Bao Y, Merrill D, Corre DL, Sproul S, Ching B, Casuga I, Sapinoso L, Desai S, Petraroli RP, Deng D, et al: Accurate and sensitive detection of KRAS mutations in heterogeneous cancer specimens. Cancer Res 71 (8 Suppl): S3071, 2011.
37. Thobe MN, Um SL, Peek VL, Ballard DW, Konicek BW, Credille KM, Ebert PJ, Donoho GP and Yan B: Detection of KRAS mutations in circulating tumor cells (CTCs) and in formalin-fixed, paraffin-embedded (FFPE) tissue using castPCR method. Cancer Res 72 (8 Suppl): S2087, 2012

38. Wang K, Liu T, Ge N, Liu L, Yuan X, Liu J, Kong F, Wang C, Ren H, Yan K, et al: TERT promoter mutations are associated with distant metastases in upper tract urothelial carcinomas and serve as urinary biomarkers detected by a sensitive castPCR Oncotarget 5: 12428-12439, 2014.

39. Bolton L, Reiman A, Lucas K, Timms J and Cree IA: KRAS mutation analysis by PCR: A comparison of two methods. PLoS One 10: e0115672, 2015.

40. Arena S, Bellosillo B, Siravegna G, Martínez A, Cañadas I, Lazzari L, Ferruz N, Russo M, Misale S, González I, et al: Emergence of multiple EGFR extracellular mutations during cetuximab treatment in colorectal cancer. Clin Cancer Res 21: 2157-2166, 2015.

41. Mansuet-Lupo A, Zouiti F, Alifano M, Tallet A, Charpentier MC, Ducruit V, Devez F, Lemaitre F, Laurent-Puig P, Damotte D and Blons H: Intratumoral distribution of EGFR mutations and copy number in metastatic lung cancer, what impact on the initial molecular diagnosis? J Transl Med 12: 131, 2014.

42. Chou TY, Chiu CH, Li LH, Hsiao CY, Tzen CY, Chang KT, Chen YM, Perng RP, Tsai SF and Tsai CM: Mutation in the tyrosine kinase domain of epidermal growth factor receptor is a predictive and prognostic factor for gefitinib treatment in patients with non-small cell lung cancer. Clin Cancer Res 11: 3750-3757, 2005.

43. Shi Y, Li J, Zhang S, Wang M, Yang S, Li N, Wu G, Liu W, Liao G, Cai K, et al: Molecular epidemiology of EGFR mutations in asian patients with advanced non-small-cell lung cancer of adenocarcinoma histology-mainland China subset analysis of the PIONEER study. PLoS One 10: e0143515, 2015.

44. Wu Y, Chu X, Wang J, Liu Z, Shen Y, Ma H, Fu X, Hu J, Zhou N, Liu Y, et al: 1175OEGFR mutation and survival outcomes in patients with completely resected lung adenocarcinoma-a multiple centers, non-interventional study (ICAN TRIAL). Ann Oncol 25 (suppl 4): iv410, 2014

45. Mitsudomi T, Morita S, Yatabe Y, Negoro S, Okamoto I, Tsurutani J, Seto T, Satouchi M, Tada H, Hirashima T, et al: Gefitinib versus cisplatin plus docetaxel in patients with non-small-cell lung cancer harbouring mutations of the epidermal growth factor receptor (WJTOG3405): An open label, randomised phase 3 trial. Lancet Oncol 11: 121-128, 2010.

46. Shigematsu H, Li L, Takahashi T, Nomura M, Suzuki M, Wistuba II, Fong KM, Lee H, Toyooka S, Shimizu N, et al: Clinical and biological features associated with epidermal growth factor receptor gene mutations in lung cancers. J Natl Cancer Inst 97: 339-345, 2005.

47. Bareschino MA, Schettino C, Rossi A, Maione P, Sacco PC, Zeppa R and Gridelli C: Treatment of advanced non small cell lung cancer. J Thorac Dis 3: 122-133, 2011.

48. Maheswaran S, Sequist LV, Nagrath S, Ulkus L, Brannigan B, Collura CV, Inserra E, Diederichs S, Iafrate AJ, Bell DW, et al: Detection of mutations in EGFR in circulating lung-cancer cells. N Engl J Med 359: 366-377, 2008.

49. Hata A, Yoshioka H, Fujita S, Kunimasa K, Kaji R, Imai Y, Tomii K, Iwasaku M, Nishiyama A, Ishida T and Katakami N: Complex mutations in the epidermal growth factor receptor gene in non-small cell lung cancer. J Thorac Oncol 5: 1524-1528, 2010.

50. Keam B, Kim DW, Park JH, Lee JO, Kim TM, Lee SH, Chung DH and Heo DS: Rare and complex mutations of epidermal growth factor receptor, and efficacy of tyrosine kinase inhibitor in patients with non-small cell lung cancer. Int J Clin Oncol 19: 594-600, 2014

51. Masago K, Fujita S, Kim YH, Ichikawa M, Hatachi Y, Fukuhara A, Nagai H, Irisa K, Mio T and Mishima M: Epidermal growth factor receptor (EGFR) double-activating somatic mutations in exons 19 and 21 in Japanese non-small cell lung cancer patients. Cancer Genet Cytogenet 195: 179-182, 2009.

52. Masago K, Togashi Y, Fukudo M, Terada T, Irisa K, Sakamori Y, Fujita S, Kim YH, Mio T, Inui KI and Mishima M: Good clinical response to erlotinib in a non-small cell lung cancer patient harboring multiple brain metastases and a double active somatic epidermal growth factor gene mutation. Case Rep Oncol 3: 98-105, 2010.

53. Peng L, Song ZG and Jiao SC: Efficacy analysis of tyrosine kinase inhibitors on rare non-small cell lung cancer patients harboring complex EGFR mutations. Sci Rep 4: 6104, 2014. 
54. Zhang GC, Lin JY, Wang Z, Zhou Q, Xu CR, Zhu JQ, Wang K, Yang XN, Chen G, Yang JJ, et al: Epidermal growth factor receptor double activating mutations involving both exons 19 and 21 exist in Chinese non-small cell lung cancer patients. Clin Oncol (R Coll Radiol) 19: 499-506, 2007.

55. Yang Y, Zhang B, Li R, Liu B and Wang L: EGFR-tyrosine kinase inhibitor treatment in a patient with advanced non-small cell lung cancer and concurrent exon 19 and 21 EGFR mutations: A case report and review of the literature. Oncol Lett 11 3546-3550, 2016.

56. Blakely CM, Lin L, Asthana S, Sidiropoulos N, Nelson T, Bastian BC, Gubens MA, Taylor BS and Bivona TG: Concurrent driver mutations in non-small cell lung cancer (NSCLC) patients (p) on targeted therapy uncovered by comprehensive molecular profiling. J Clin Oncol 31 (15 Suppl): S1904, 2013.

57. Schmid K, Oehl N, Wrba F, Pirker R, Pirker C and Filipits M: EGFR/KRAS/BRAF mutations in primary lung adenocarcinomas and corresponding locoregional lymph node metastases. Clin Cancer Res 15: 4554-4560, 2009.

58. Cardarella S, Ogino A, Nishino M, Butaney M, Shen J, Lydon C, Yeap BY, Sholl LM, Johnson BE and Jänne PA: Clinical, pathologic, and biologic features associated with BRAF mutations in non-small cell lung cancer. Clin Cancer Res 19: 4532-4540, 2013.

59. Sasaki H, Shitara M, Yokota K, Okuda K, Hikosaka Y, Moriyama S, Yano M and Fujii Y: Braf and erbB2 mutations correlate with smoking status in lung cancer patients. Exp Ther Med 3: 771-775, 2012

60. Kobayashi M, Sonobe M, Takahashi T, Yoshizawa A, Ishikawa M, Kikuchi R, Okubo K, Huang CL and Date H: Clinical significance of BRAF gene mutations in patients with non-small cell lung cancer. Anticancer Res 31: 4619-4623, 2011.

61. Kinno T, Tsuta K, Shiraishi K, Mizukami T, Suzuki M, Yoshida A, Suzuki K, Asamura H, Furuta K, Kohno T and Kushima R: Clinicopathological features of nonsmall cell lung carcinomas with BRAF mutations. Ann Oncol 25: 138-142, 2014.

62. Brustugun OT, Khattak AM, Trømborg AK, Mizukami T, Suzuki M, Yoshida A, Suzuki K, Asamura H, Furuta K, Kohno T and Kushima R: BRAF-mutations in non-small cell lung cancer. Lung Cancer 84: 36-38, 2014.

63. Zheng G, Tseng LH, Chen G, Haley L, Illei P, Gocke CD, Eshleman JR9 and Lin MT: Clinical detection and categorization of uncommon and concomitant mutations involving BRAF. BMC Cancer 15: 779, 2015.

64. Gao J, Wu H, Shi X, Huo Z, Zhang J and Liang Z: Comparison of next-generation sequencing, quantitative PCR and sanger sequencing for mutation profiling of EGFR, KRAS, PIK3CA and BRAF in clinical lung tumors. Clin Lab 62: 689-696, 2016

65. Marchetti A, Felicioni L, Malatesta S, Grazia Sciarrotta M, Guetti L, Chella A, Viola P, Pullara C, Mucilli F and Buttitta F: Clinical features and outcome of patients with non-small-cell lung cancer harboring BRAF mutations. J Clin Oncol 29: 3574-3579, 2011

66. Tissot C, Couraud S, Tanguy R, Bringuier PP, Girard N and Souquet PJ: Clinical characteristics and outcome of patients with lung cancer harboring BRAF mutations. Lung Cancer 91: 23-28, 2016.

67. Pao W and Girard N: New driver mutations in non-small-cell lung cancer. Lancet Oncol 12: 175-180, 2011.

68. Leon SA, Shapiro B, Sklaroff DM and Yaros MJ: Free DNA in the serum of cancer patients and the effect of therapy. Cancer Res 37: 646-650, 1977.

69. Pratilas C, Hanrahan AJ, Halilovic E, Persaud Y, Soh J, Chitale D, Shigematsu H, Yamamoto H, Sawai A, Janakiraman M, et al: Genetic predictors of MEK-dependence in non-small cell lung cancer. Cancer Res 68: 9375-9383, 2008.

70. An SJ, Chen ZH, Su J, Zhang XC, Zhong WZ, Yang JJ, Zhou Q, Yang XN, Huang L, Guan JL, et al: Identification of enriched driver gene alterations in subgroups of non-small cell lung cancer patients based on histology and smoking status. PLoS One 7: e40109, 2012.

71. Bahadoran P, Allegra M, Le Duff F, Long-Mira E, Hofman P, Giacchero D, Passeron T, Lacour JP and Ballotti R: Major clinical response to a BRAF inhibitor in a patient with a BRAF L597R-mutated melanoma. J Clin Oncol 31: e324-e326, 2013.
72. Sequist LV, Martins RG, Spigel D, Grunberg SM, Spira A, Jänne PA, Joshi VA, McCollum D, Evans TL, Muzikansky A, et al: First-line gefitinib in patients with advanced non-small-cell lung cancer harboring somatic EGFR mutations. J Clin Oncol 26: 2442-2494, 2008.

73. Nakamura T, Sueoka-Aragane N, Iwanaga K, Sato A, Komiya K, Abe T, Ureshino N, Hayashi S, Hosomi T, Hirai M, et al: A noninvasive system for monitoring resistance to epidermal growth factor receptor tyrosine kinase inhibitors with plasma DNA. J Thorac Oncol 6: 1639-1648, 2011.

74. Rosell R, Molina MA, Costa C, Simonetti S, Gimenez-Capitan A, Bertran-Alamillo J, Mayo C, Moran T, Mendez P, Cardenal F, et al: Pretreatment EGFR T790M mutation and BRCA1 mRNA expression in erlotinib-treated advanced non-small-cell lung cancer patients with EGFR mutations. Clin Cancer Res 17: 1160-1168, 2011.

75. Wu JY, Yu CJ, Chang YC, Yang CH, Shih JY and Yang PC: Effectiveness of tyrosine kinase inhibitors on 'uncommon' epidermal growth factor receptor mutations of unknown clinical significance in non-small cell lung cancer. Clin Cancer Res 17: 3812-3821, 2011.

76. Fujita Y, Suda K, Kimura H, Matsumoto K, Arao T, Nagai T, Saijo N, Yatabe Y, Mitsudomi T and Nishio K: Highly sensitive detection of EGFR T790M mutation using colony hybridization predicts favorable prognosis of patients with lung cancer harboring activating EGFR mutation. J Thorac Oncol 7: 1640-1644, 2012.

77. Su KY, Chen HY, Li KC, Kuo ML, Yang JC, Chan WK, Ho BC, Chang GC, Shih JY, Yu SL and Yang PC: Pretreatment epidermal growth factor receptor (EGFR) T790M mutation predicts shorter EGFR tyrosine kinase inhibitor response duration in patients with non-small-cell lung cancer. J Clin Oncol 30: 433-440, 2012.

78. Sakai K, Horiike A, Irwin DL, Kudo K, Fujita Y, Tanimoto A, Sakatani T, Saito R, Kaburaki K, Yanagitani N, et al: Detection of epidermal growth factor receptor T790M mutation in plasma DNA from patients refractory to epidermal growth factor receptor tyrosine kinase inhibitor. Cancer Sci 104: 1198-1204, 2013

79. Costa C, Molina MA, Drozdowskyj A, Giménez-Capitán A, Bertran-Alamillo J, Karachaliou N, Gervais R, Massuti B, Wei J, Moran T, et al: The impact of EGFR T790M mutations and BIM mRNA expression on outcome in patients with EGFR-mutant NSCLC treated with erlotinib or chemotherapy in the randomized phase III EURTAC trial. Clin Cancer Res 20: 2001-2002, 2014.

80. Yu HA, Arcila ME, Hellmann MD, Kris MG, Ladanyi M and Riely GJ: Poor response to erlotinib in patients with tumors containing baseline EGFR T790M mutations found by routine clinical molecular testing. Ann Oncol 25: 423-428, 2014.

81. Miyazawa H, Tanaka T, Nagai Y, Matsuoka M, Huqun, Sutani A, Udagawa K, Zhang J, Hirama T, Murayama Y, et al: Peptide nucleic acid-locked nucleic acid polymerase chain reaction clamp-based detection test for gefitinib-refractory T790M epidermal growth factor receptor mutation. Cancer Science 99: 595-6600, 2008.

82. Li J, Wang L, Jänne PA and Makrigiorgos GM: Coamplification at lower denaturation temperature-PCR increases mutation-detection selectivity of TaqMan-based real-time PCR. Clin Chem 55: 748-756, 2009.

83. Chen HJ, Mok TS, Chen ZH, Guo AL, Zhang XC, Su J and $\mathrm{Wu}$ YL: Clinicopathologic and molecular features of epidermal growth factor receptor T790M mutation and c-MET amplification in tyrosine kinase inhibitor-resistant Chinese non-small cell lung cancer. Pathol Oncol Res 15: 651-658, 2009.

84. Oh YH, Kim Y, Kim YP, Seo SW, Mitsudomi T, Ahn MJ, Park K and Kim HS: Rapid detection of the epidermal growth factor receptor mutation in non-small-cell lung cancer for analysis of acquired resistance using molecular beacons. J Mol Diagn 12: 644-652, 2010

85. Oh JE, An CH, Yoo NJ and Lee SH: Detection of low-level EGFR, T790M mutation in lung cancer tissues. APMIS 119: 403-411, 2011.

86. Taniguchi K, Uchida J, Nishino K, Kumagai T, Okuyama T, Okami J, Higashiyama M, Kodama K, Imamura F and Kato K: Quantitative detection of EGFR mutations in circulating tumor DNA derived from lung adenocarcinomas. Clin Cancer Res 17: 7808-7815, 2011 
87. Arcila ME, Oxnard GR, Nafa K, Riely GJ, Solomon SB, Zakowski MF, Kris MG, Pao W, Miller VA and Ladanyi M: Rebiopsy of lung cancer patients with acquired resistance to EGFR inhibitors and enhanced detection of the T790M mutation using a locked nucleic acid-based assay. Clin Cancer Res 17: 1169-1180, 2011.

88. Guha M, Castellanos-Rizaldos E and Makrigiorgos GM: DISSECT method using PNA-LNA clamp improves detection of EGFR T790m mutation. PLoS One 8: e67782, 2013.
89. He C, Zheng L, Xu Y, Liu M, Li Y and Xu J: Highly sensitive and noninvasive detection of epidermal growth factor receptor T790M mutation in non-small cell lung cancer. Clin Chim Acta 425: 119-124, 2013

90. Kim HJ, Oh SY, Kim WS, Kim SJ, Yoo GH, Kim WD and Lee KY: Clinical investigation of EGFR mutation detection by pyrosequencing in lung cancer patients. Oncol Lett 5: 271-276, 2013. 